\title{
Determinants of Commercial Banks' Performance in Malawi: A Triple Autoregressive Distributed Lag (ARDL) Approach
}

\author{
Lloyd George Banda \\ The Reserve Bank of Malawi, P.O Box 565, Henderson Street, Blantyre
}

\begin{abstract}
There has been a monotonic increase in research investigating the performance of commercial banks across the globe. This is a recognition that the banking and financial sector has a significant contribution to the service sector and national output. This paper analyzed the determinants of commercial bank's performance in the category of macroeconomic, bank-specific and financial structure factors in Malawi. The study employed an autoregressive distributed (ARDL) approach/bounds cointegration testing for a period between 1990 to 2020 . The results show that inflation has a negative and statistically significant relationship with bank's ROA in the long run. While cost-to-income ratio also depicts a negative and statistically significant relationship with all the indicators of bank performance (ROA, ROE and NIM) in the long run. On the other hand, bank concentration is insignificant on all the models. The paper suggests various policy implications to on internal and external determinants of commercial bank's performance.
\end{abstract}

Keywords: ROA, ROE, NIM, ARDL, Inflation, Cost-to-income ratio, bank concentration

DOI: $10.7176 /$ RJFA/12-17-03

Publication date:September $30^{\text {th }} 2021$

\subsection{Introduction}

Commercial banks are an important service character in the development of a country's economy and its financial system. Commercial banks are vital institutions in any society as they significantly contribute to the development of an economy through facilitation of business and market activities in general. Banks facilitate the development of saving plans and are instruments of the government's monetary strategies among others. The contribution of the primary sector to GDP has been hyped mainly because $80 \%$ of the population in Malawi live in rural areas and depend on agriculture. In essence, it is the service sector which is a major contributor to the country's GDP of $55.61 \%$ in 2020 and also employs $18 \%$ of the workforce in the country. The main activities in the tertiary sector is dominated by the financial sector and banking sector in particular followed by retail services, telecommunications, tourism, and healthcare services (KPMG, 2017).

Commercial banks receive deposits from people and lend out the money to those who need it for business or legal purposes. In recent years, commercial banks in Malawi have slowly increased their product and services such as online banking, self-deposit boxes, credit card and more. Therefore, the performance of commercial banks is very vital not only for the financial system of a country but also its overall economic development. Commercial banks must make sure that they are able to improve the quality of their services to satisfy the expectation of customers, maintain financial stability as well as improve their performance leading towards an efficient financial system.

This study, therefore, seeks to investigate the determinants of banking performance in Malawi. According to Ozili (2019), a sounding performance in the banking sector is crucial to the stability of any financial system in the world. As such, the central bank in Malawi legally known as the Reserve Bank of Malawi (RBM) as a financial system regulator understands that a loss of confidence in the banking system can have devastating consequences for the entire financial system and national economy. As such, stability of the banking sector has always been a top regulatory and supervisory policy objective for the Reserve Bank.

The major objective of this study is to determine the factors affecting commercial bank's performance in Malawi. Numerous similar researches have been done oversees by other scholars but there is less that has been conducted in Malawi. The study differs from prior studies in Malawi in that it is primarily interested in aggregate outcomes rather than in individual bank performance as Lipunga (2014) and Mkandawire (2016) who focused only on four largest banks. Using aggregate outcomes allows us to focus on the changes occurring in the Malawian banking industry. The study uses rate of return on assets, rate of return on equity and net-interest margin the measure of performance of commercial banks in Malawi. The explanatory variables include inflation, bank's cost-to-income ratio and bank's concentration ratio in the category of macroeconomic factors, bankspecific factors and financial structure factors respectively.

\subsection{Literature Review}

The performance of commercial banks is unanimously a function of bank-specific determinants, macroeconomic determinants and the structure of the financial sector determinants. Bank specific factors are usually as a result of management strategy and other financial conditions that arguably reflect or are as a result of management 
decisions and financial capacity of the shareholders of the bank while macroeconomic factors and financial structure combined are external factors which reflect the legal and economic environment which can influence the process and performance of commercial banks over which management is devoid of control (Mkandawire, 2016).

Researchers have explored various commercial bank-specific variables that affect the performance of commercial banks such as cost-to-income ratio, bank size, capital adequacy, ownership (government or private), liquidity and risk (Mkandawire, 2016; Jeng, et al, 2018; Ozili, 2018; Chirwa, 2001; Lipunga, 2014; Delis \& Staikouras, 2006). While, macroeconomic determinants include Inflation, exchange rate fluctuations, interest rates, Reserves, market concentration, economic growth, money supply and other legal and regulatory factors. (Ozili, 2019; Anbar \& Alper, 2017; Kaluwa \& Chirwa, 2017). On the other hand, Financial structure determinants includes total market deposit, bank concentration ratio, financial liberalization, bank pricing, regulations or policies (Chirwa, 2001; Mkandawire, 2016; Kaluwa \& Chirwa, 2017).

\subsection{Trend Analysis of Banking and Financial Sector in Malawi}

\subsection{Malawi's Banking and Financial Services'\% of Service Imports (BFSM) and Exports (BFSX)}

In 2019 , insurance and financial services accounted for $24.4 \%$ of services exports and $9.5 \%$ of services imports (see Figure 3a). Albeit, the Banking and financial sector seems to have a surplus after 2012, Malawi is a net importer of total services with a trade deficit of $\$ 176$ million $(\$ 358 \mathrm{~m}$ minus $\$ 182 \mathrm{~m}$ in 2019 .

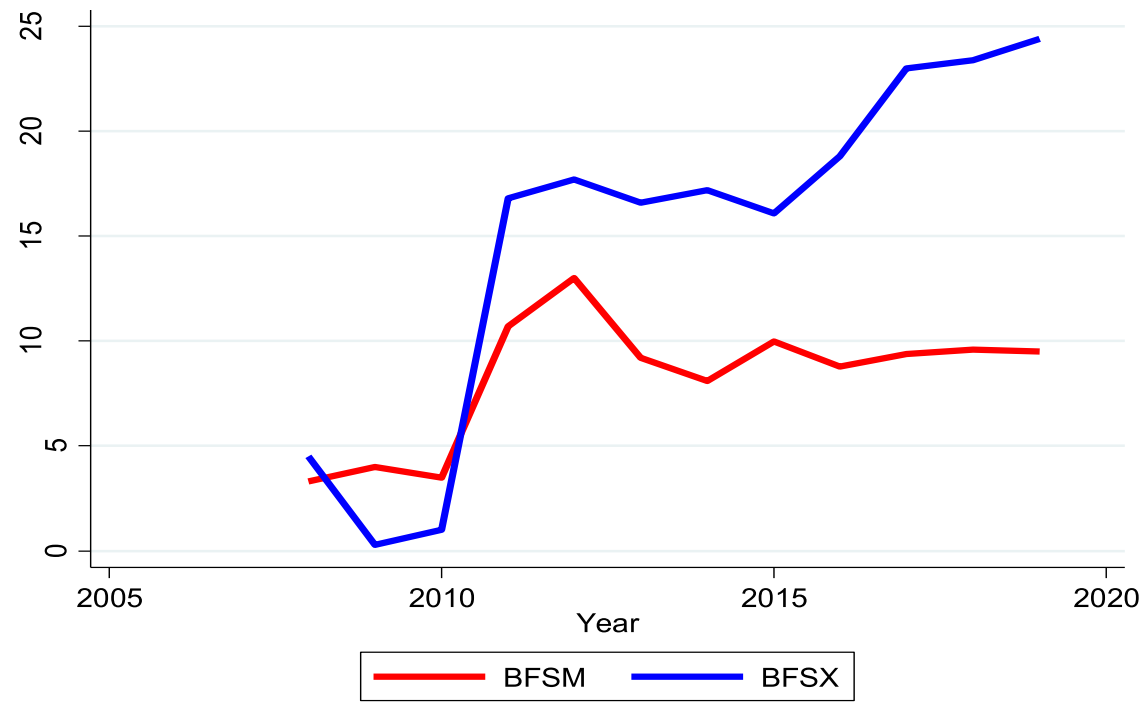

Source: Author's computation of data from Knoema

\subsection{Trend Analysis of Commercial Bank's Performance Using ROA, ROE and NIM}

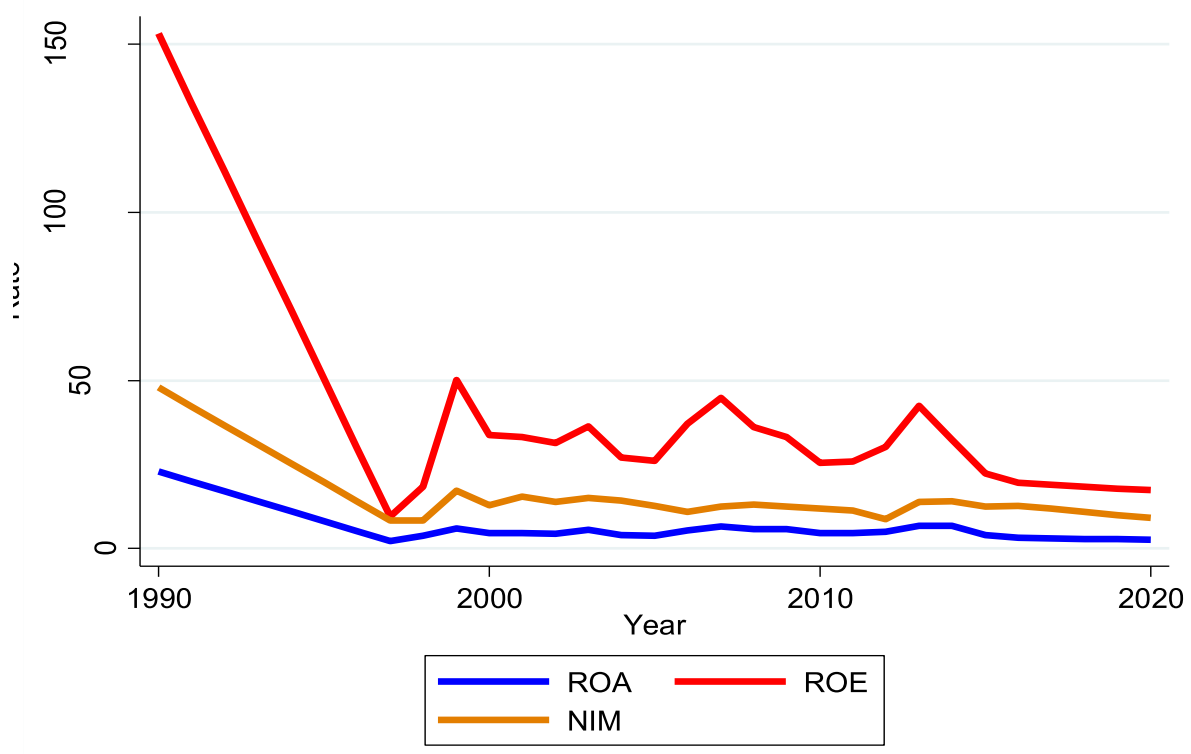

Source: Author's computation of data from Humanitarian Data Exchange 
Figure $3 \mathrm{~b}$ clearly shows that in 1990, bank performance was very high at the grasp of all the indicators. During this time, there were only three banks in operational namely' National Bank (1971), Standard Bank (1961) and Nedbank (1976). Commercial bank's performance then started decreasing as the number of banks started increasing, that is, First Capital Bank (1995), Continental Discount Holdings (1998) up to around 2000s. The commercial bank's performance started fluctuation with constant ups and downs as the number of commercial banks kept increasing. That is, New Building Society (2004), First Discount Holdings - FDH Financial Holdings (2007) and MyBacks Banking Corporation (2014).

\subsection{Data, scope and estimation procedure}

\subsection{Data definitions and sources}

In order to examine the relationship between the variables, this study employs the Malawian annual time series from 1990 to 2020. Malawi's commercial bank rate of return on assets, rate of return on equity and net interest margin are adopted as a proxy for commercial bank's performance and are obtained from the Humanitarian Data Exchange database. The table below summarizes all dependent and independent variables.

Table 4.1: Variable introduction and data sources

\begin{tabular}{|l|l|l|l|}
\hline Variables & Codes & Parameters & Sources \\
\hline Return on assets & ROA & Rate of return on assets & $\begin{array}{l}\text { Humanitarian } \\
\text { Data Exchange }\end{array}$ \\
\hline Return on equity & ROE & Rate of return on equity & $\begin{array}{l}\text { Humanitarian } \\
\text { Data Exchange }\end{array}$ \\
\hline Net interest margin & NIM & Net interest income & $\begin{array}{l}\text { Humanitarian } \\
\text { Data Exchange }\end{array}$ \\
\hline Inflation & INF & Annual inflation (\%) & $\begin{array}{l}\text { Reserve } \\
\text { of Malawi }\end{array}$ \\
\hline Bank concentration & CON & Bank concentration ratio & $\begin{array}{l}\text { Humanitarian } \\
\text { Data Exchange }\end{array}$ \\
\hline Bank cost to income & CTY & Bank cost to income ratio & $\begin{array}{l}\text { Humanitarian } \\
\text { Data Exchange }\end{array}$ \\
\hline
\end{tabular}

\subsection{Theoretical Framework}

The study adopted the framework used by Jeng, et al (2018) with only a difference in the variables used as well as data estimation technique. This is shows as follows:

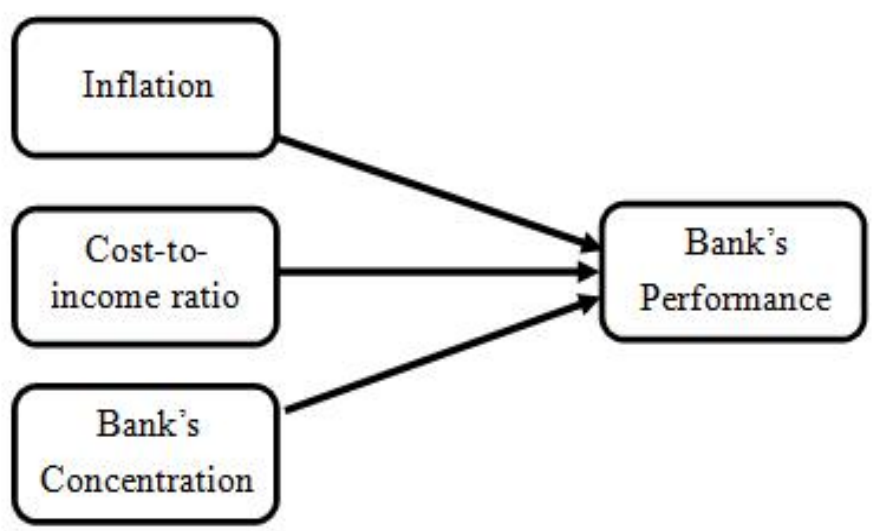

Where commercial bank's performance is measured by ROA, ROE and NIM;

ROA - bank's rate of return on assets is a financial ratio that indicate the profitability of a bank. It measures the net income earned on assets of a bank or institution and how well the company uses its total assets to generate income returns. This indicator gives meaning on how effectively the banks used its total resources to generate income. It is calculated by dividing the company's net income after tax by its own assets. The higher the ROA number, the better the performance since commercial banks will be earning more money on less investments.

ROE - bank's rate of return on equity measures how much profit a bank can generate by using the total amount of shareholder's equity. In other words, it is a financial ratio used to identify bank's administrative efficiency to use the shareholder's investment. The greater the ROE value, the higher the chances that investors will be attracted to invest as it implies a better performance of the company. Most commercial banks use the monetary control to maintain or increase their ROE to gain competitive advantage (Jumar, et al, 2020). ROE is calculated by net profit after tax by shareholders' equity. 
NIM - is the bank's net interest margin defined as the performance metric that examine how effective a bank's investment decisions can be compared to its debt situation. It is also defined as the net yield on the interest earning assets and it is important in tracking and assessing the bank's profitability from investing and lending activities over a period of time. NIM is measured by interest income minus interest expenses and divided by average earning assets. Most importantly, a positive net interest margin suggests that an entity operates profitably, while a negative value implies investment inefficiency.

INFL - inflation is an important macroeconomic factor which reflects a reduction in the purchasing power of a currency in a country. When there is inflation, each unit of currency purchases fewer goods and services (Jeng, et al, 2018; Lipsey \& Chrystal, 2015).

CON - Concentration ratio is a measure of the financial structure, especially the banking sector. This study aims to measure the effect of 3-bank concentration ratio on bank's performance. The hypothesis is such that the greater the concentration ratio, the greater the percentage of total banking assets are owned by few banks and hence the less the competition in the banking sector. High concentration ratio is an evidence that the banking sector of a country is dominated by few banks. Though, larger banks may have greater efficiency, higher profitability and diversification. On the contrary, low concentration ratio simply means that the major banks control a low proportion of assets and that minor banks are fairly competitive.

CTY - is the bank's cost to income ratio which measures the cost of running the banks compared to their operating income. It is calculated by the operating expenses divided by the operating income generated. That is, net interest income plus the other income. Cost to income is an important financial ratio in determining the profitability of banks. There is an inverse relationship, such that, the lower the cost-to-income ratio implies more profitability of the bank.

\subsection{Methodology}

The model specification adopted for this study is similar to the model of Ozili (2019). The functional form of the model is linear, and is expressed below:

Banking performance $=f$ (macroeconomic factors + bank specific factors + financial structure)

(1)

Depending on the three dependent variables employed in this study, function (1) can econometrically be transformed as:

$$
\begin{aligned}
& R O A=\lambda_{0}+\lambda_{1} I N F L+\lambda_{2} C T Y+\lambda_{3} C O N . \\
& R O E=\lambda_{0}+\lambda_{1} I N F L+\lambda_{2} C T Y+\lambda_{3} C O N . \\
& N I M=\lambda_{0}+\lambda_{1} I N F L+\lambda_{2} C T Y+\lambda_{3} C O N .
\end{aligned}
$$

The study adopts the Autoregressive Distributed Lag (ARDL)/bounds testing cointegration procedure to estimate the long run and short run relationships and dynamic interactions among the variables of interests. Pesaran et al. (2001) proposed an ARDL/Bounds Testing approach to investigate the existence of cointegration relationship among variables. Udol et al (2015) outline three specific advantages associated with this approach:

i. It circumvents the problem of the order of integration associated with Johansen likelihood approach;

ii. Unlike most of the convectional multivariate cointegration procedures, which are valid for large sample size, the bounds test approach is suitable for small sample size study (pesaran et al, 2001); and

iii. It provides unbiased estimates of the long-run model and valid t-statistics even when some of the regressors are endogenous (Harris and Sollis, 2003).

The following three ARDL models will be estimated in order to test the cointegration relationship between the variables: return on assets, return on equity, net interest margin, inflation, concentration ratio and cost-to-income ratio;

$\triangle \ln R O A_{t}=c_{0}+\delta_{1} \ln R O A+\delta_{2} \ln I N F L+\delta_{3} \ln C T Y+\delta_{4} \ln C O N+\sum_{i=1}^{p} \emptyset_{i} \Delta \ln R O A_{t-i}+\sum_{j=0}^{q 1} \gamma_{j} \Delta \ln l N F_{t-j}+$ $\sum_{k=1}^{q 2} \varphi_{k} \Delta \ln C T Y_{t-k}+\sum_{l=i}^{q 3} \vartheta_{l} \Delta \ln C O N_{t-l}+\varepsilon_{t}$

$\triangle \ln R O E_{t}=c_{0}+\delta_{1} \ln R O A+\delta_{2} \ln I N F L+\delta_{3} \ln C T Y+\delta_{4} \ln C O N+\sum_{i=1}^{p} \emptyset_{i} \Delta \ln R O A_{t-i}+\sum_{j=0}^{q 1} \gamma_{j} \Delta \ln I N F_{t-j}+$ $\sum_{k=1}^{q 2} \varphi_{k} \Delta \ln C T Y_{t-k}+\sum_{l=\mathrm{i}}^{q 3} \vartheta_{l} \Delta \ln C O N_{t-l}+\varepsilon_{t}$

$\Delta \ln N I M_{t}=c_{0}+\delta_{1} \ln R O A+\delta_{2} \ln I N F L+\delta_{3} \ln C T Y+\delta_{4} \ln C O N+\sum_{i=1}^{p} \emptyset_{i} \Delta \ln R O A_{t-i}+\sum_{j=0}^{q 1} \gamma_{j} \Delta \ln I N F_{t-j}+$ $\sum_{k=1}^{q 2} \varphi_{k} \Delta \ln C T Y_{t-k}+\sum_{l=i}^{q 3} \vartheta_{l} \Delta \ln C O N_{t-l}+\varepsilon_{t}$

Where; $\Delta$ is the difference operator, $\delta_{i}$ are the long run multipliers, $c_{0}$ is the intercept and $\varepsilon_{t}$ is white noise error.

The first step in the ARDL bounds testing approach is to estimate equation (1) by Ordinary Least Squares (OLS) in order to test for the existence of a long run relationship among the variables by conducting an F-test for 
the joint significance of the coefficients of the lagged levels of the variables, that is:

$H_{0}: \delta_{1}=\delta_{2}=\delta_{3}=\delta_{4}$, against the alternative

$H_{0}: \delta_{1} \neq \delta_{2} \neq \delta_{3} \neq \delta_{4}$,

We denote the test which normalizes on ROA, ROE and NIM by $F_{\text {ROA }}$ (ROA|INFL, CTY, CON), $F_{R O E}(\mathrm{ROE} \mid \mathrm{INFL}, \mathrm{CTY}, \mathrm{CON}), F_{\text {NIM }}(\mathrm{NIM} \mid \mathrm{INFL}, \mathrm{CTY}, \mathrm{CON})$ respectively. Two asymptotic critical values bounds provide a test for cointegration when the independent variables are $\mathrm{I}(\mathrm{d})$ [where $0 \leq d \leq 1]$ : a lower value assuming the regressors are $\mathrm{I}(0)$ and an upper value assuming purely $\mathrm{I}(1)$ regressors. If the F-statistic is above the upper critical value, the null hypothesis of no long run relationship can be rejected irrespective of the orders of integration for the time series. Conversely, if the test statistic falls below the lower critical value, the null hypothesis cannot be rejected. Finally, if the statistics (F or T) falls between the lower and upper critical values, the result is inconclusive. Regarding this study, the approximate critical values for the F-statistic test were obtained from Pesaran et al (2001).

Once cointegration is established, the conditional ARDL (p, q1, q2, q3) long-run model for $R O A_{t}, R O E_{t}, N I M_{t}$ can be estimated as:

$$
\begin{aligned}
& \triangle \ln R O A_{t}=c_{0}+\sum_{i=1}^{p} \delta_{1} \Delta \ln R O A_{t-1}+\sum_{j=0}^{q 1} \delta_{2} \Delta \ln I N F L_{t-j}+\sum_{k=1}^{q 2} \delta_{3} \Delta \ln C T Y_{t-k}+\sum_{l=i}^{q 3} \delta_{4} \Delta \ln C O N_{t-l}+\varepsilon_{t} \\
& \triangle \ln R O E_{t}=c_{0}+\sum_{i=1}^{p} \delta_{1} \Delta \ln R O A_{t-i}+\sum_{j=0}^{q 1} \delta_{2} \Delta \ln I N F L_{t-j}+\sum_{k=1}^{q 2} \delta_{3} \Delta \ln C T Y_{t-k}+\sum_{i=i}^{q 3} \delta_{4} \Delta \ln C O N_{t-1}+\varepsilon_{\mathrm{t}} \\
& \Delta \operatorname{lnNIM_{t}}=c_{0}+\sum_{i=1}^{p} \delta_{1} \Delta \ln R O A_{t-i}+\sum_{j=0}^{q 1} \delta_{2} \Delta \ln I N F L_{t-j}+\sum_{k=1}^{q 2} \delta_{3} \Delta \ln C T Y_{t-k}+\sum_{l=i}^{q 3} \delta_{4} \Delta \ln C O N_{t-1}+\varepsilon_{t}
\end{aligned}
$$

This involves selecting the orders of the ARDL (P, q1, q2, q3) model in the three models in the four variables using Akaike Information Criteria (AIC). The next move is to obtain the short-run dynamic parameters by estimating an error correction model associated with the long-run estimates. This is specified as:

$$
\begin{aligned}
& \Delta \ln R O A_{t}=u+\sum_{i=1}^{p} \emptyset_{i} \Delta \ln R O A_{t-i}+\sum_{j=0}^{q 1} \gamma_{j} \Delta \ln I N F L_{t-j}+\sum_{k=1}^{q 2} \varphi_{k} \Delta \ln C T Y_{t-k}+ \\
& \sum_{l=i}^{q 3} \vartheta_{l} \Delta \ln C O N_{t-l}+\delta E C T_{t-l}+\varepsilon_{t}
\end{aligned}
$$$$
\Delta \ln R O A_{t}=u+\sum_{i=1}^{p} \emptyset_{i} \Delta \ln R O A_{t-i}+\sum_{j=0}^{q 1} \gamma_{j} \Delta \ln I N F L_{t-j}+\sum_{k=1}^{q 2} \varphi_{k} \Delta \ln C T Y_{t-k}+
$$$$
\sum_{l=i}^{q^{3}} \vartheta_{l} \Delta \operatorname{lnCON_{t-l}}+\delta E C T_{t-l}+\varepsilon_{t}
$$

$\Delta \ln R O E_{t}=u+\sum_{i=1}^{p} \emptyset_{i} \Delta \ln R O A_{t-i}+\sum_{j=0}^{q 1} \gamma_{j} \Delta \ln I N F L_{t-j}+\sum_{k=1}^{q 2} \varphi_{k} \Delta \ln C T Y_{t-k}+$ $\sum_{l=i}^{q 3} \vartheta_{l} \Delta l n C O N_{t-l}+\delta E C T_{t-l}+\varepsilon_{t}$

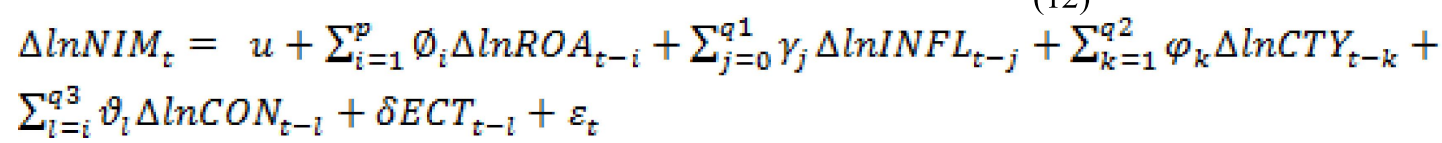

In this case, $\varphi, \phi$, and $\gamma$ are the short-run dynamic coefficients of the model's convergence to equilibrium and $\theta$ is the speed of adjustment.

\subsection{Empirical Results}

5.1. Descriptive Statistics

Table 5.1a: Descriptive statistics

\begin{tabular}{|l|l|l|l|l|l|l|}
\hline & ROA & ROE & NIM & INFL & CTY & CON \\
\hline Mean & 6.675528 & 42.85827 & 16.46515 & 20.18239 & 29.7526 & 94.41709 \\
\hline Std. dev & 5.102664 & 34.40037 & $9.850822^{2}$ & $15.31472^{2}$ & 55.1187 & 9.327946 \\
\hline Minimum & $2.2490_{1997}$ & $9.4347_{1997}$ & $8.3789_{1998}$ & 7.411591 & -149.1055 & 84.179 \\
\hline Maximum & $22.938_{1990}$ & $153.15_{1990}$ & $2.2490_{1990}$ & 83.32577 & 78.2832 & 121.6742 \\
\hline Obs. & 31 & 21 & 31 & 31 & 31 & 31 \\
\hline
\end{tabular}

The reported summary results in table 5.1a indicates that Malawian banks are fairly profitable, with all banks registering an average increase of $6.7 \%$ over the 31 years of study. Earnings from shareholder investments also shows fair efficiency with an average value of $16.47 \%$. On the other hand, interest earnings from loans relative to interest paid on deposits shows a positive and good value of $20.18 \%$. The cost-to-income ratio shows an average of 29.75 which means commercial banks in Malawi need relatively small operating costs to generate income, but the maximum value was too high at $78.28 \%$ in 1997 . Inflation in Malawi is very high with an 
average of $20.18 \%$ and a maximum of $83.32 \%$ in 1995 . It also shows that the banking sector's share of assets is dominated by the largest three banks with an average value of $94.41 \%$.

\subsection{Unit roots Tests}

A nonstationary series may violate the basic assumption in the econometric model (Khan, et al, 2020). Before proceeding towards the autoregressive distributed lag (ARDL) approach, the first step is to ascertain the unit root properties of the series. The commonly used unit root tests are by Dicky and Fuller (1979), Phillips and Perron (1988), Dickey-Fuller Generalized Least Squares by Elliot et al (DF-GLS) (1996), and Kwiatkowski et at. (KPSS) (1992) The study adopted the Augmented Dickey-Fuller (ADF) test to determine the stationarity of the data used in the series and the results interpreted in absolute values are shown in the table below:

Table 5.1: Results of ADF unit root test

\begin{tabular}{|l|c|c|c|c|c|}
\hline \multicolumn{7}{|c|}{ Augmented Dickey Fuller } \\
\hline Variable & Test Statistic & $\mathbf{1 \%}$ Critical & $\mathbf{5 \%}$ Critical & $\mathbf{1 0 \%}$ Critical & Order of integration \\
\hline$\Delta \operatorname{lnROA}$ & -4.621 & -4.352 & -3.588 & -3.233 & $\mathrm{I}(1)$ \\
\hline$\Delta \operatorname{lnROE}$ & -5.071 & -4.352 & -3.588 & -3.233 & $\mathrm{I}(1)$ \\
\hline$\Delta \operatorname{lnNIM}$ & -5.505 & -4.343 & -3.584 & -3.230 & $\mathrm{I}(1)$ \\
\hline$\Delta \operatorname{lnINFL}$ & -5.790 & -4.352 & -3.588 & -3.233 & $\mathrm{I}(1)$ \\
\hline$\Delta \ln \mathrm{CTY}$ & -32.806 & -4.343 & -3.584 & -3.230 & $\mathrm{I}(1)$ \\
\hline$\Delta \operatorname{lnCON}$ & -6.011 & -4.352 & -3.588 & -3.233 & $\mathrm{I}(1)$ \\
\hline
\end{tabular}

As shown above, all variables were stationary after differencing once I(1), and this made it possible to estimate the results using an Autoregressive Distributed Lag model (ARDL) unlike the Ordinary Least Squares (OLS) regression technique which would lead to meaningless results of a phenomenon called spurious regression (Granger \& Newbold, 1974). The variables are expressed in their natural logarithms. D denotes first difference. The null hypothesis has been rejected at $5 \%$ significant level for all variables.

\subsection{Cointegration test}

Using AIC as a guide, a maximum lag order of 2 and 4 was chosen for the ARDL models. Table 5.2 reports the results of the calculated F-statistics for each dependent variable of the study in the ARDL OLS regression.

Table 5.2a: Results of Bounds Tests

\begin{tabular}{|l|c|c|c|c|}
\hline \multicolumn{1}{|c|}{ Dependent Variable } & Lag & F-statistic & Upper Bound & Outcome \\
\hline$\Delta \operatorname{lnROA}$ & 4 & 9.836 & $5.61^{* * *}$ & Cointegration \\
\hline$\Delta \operatorname{lnROE}$ & 2 & 10.274 & $5.61^{* * *}$ & Cointegration \\
\hline$\Delta \operatorname{lnNIM}$ & 2 & 10.117 & $5.61^{* * *}$ & Cointegration \\
\hline
\end{tabular}

Notes: $* \mathrm{P}<0.10, \quad * * \mathrm{P}<0.05, \quad * * * \mathrm{P}<0.01$

When the regression is normalized on Return on Asset (ROA), Return on Equity (ROE) and Net Interest Margin (NIM), the calculated F-statistics are higher than the upper bound critical values at $1 \%$ and $5 \%$ significance level. Thus, the null hypothesis of no cointegration is rejected, implying long-run cointegration relationships amongst the variables in each model.

Following the establishment of a long-run cointegration relationship, equations (7, 8 \& 9) were estimated. The results obtained by normalizing on the dependent variables in the error correction are reported in table 5.2b, $5.2 \mathrm{c}$ and $5.2 \mathrm{~d}$ for dependent variables ROA, ROE and NIM respectively. 
Table 5.2b: Error Correction model for ROA (short and long-run model)

Dependent Variable: $\Delta \ln R O A$

Long-run results

\begin{tabular}{lllll}
\hline Regressor & Coefficient & Standard Error & t-Statistic & Prob (t-Statistic) \\
\hline Constant & 0.0075504 & 0.0395106 & 0.19 & 0.850 \\
$\Delta \operatorname{lnINFL}$ & 0.2088732 & 0.1026529 & 2.33 & 0.050 \\
$\Delta \operatorname{lnCTY}$ & -2.837639 & 0.977298 & -2.90 & 0.009 \\
$\Delta \operatorname{lnCON}$ & 0.6734405 & 2.667904 & 0.25 & 0.803 \\
\hline
\end{tabular}

Short run results

$\begin{array}{lllll}\mathrm{D} 1 . \Delta \ln \mathrm{NF} & \wedge & \wedge & \wedge & \wedge\end{array}$

LD. $\triangle \operatorname{lnINFL}$

\begin{tabular}{lllll}
\hline D1. $\Delta \operatorname{lnCTY}$ & -0.8786849 & 0.9516803 & -0.92 & 0.367 \\
LD. $\Delta \operatorname{lnCTY}$ & -0.1897426 & 0.1298372 & -1.46 & 0.159 \\
\hline D1. $\Delta \operatorname{lnCON}$ & -1.747057 & 1.335649 & -1.31 & 0.206 \\
LD. $\Delta \operatorname{lnCON}$ & $\wedge$ & $\wedge$ & \\
\hline ECTt-1 & -0.7739404 & 0.2114385 & -3.66 & 0.002 \\
\hline R-squared & $\mathbf{0 . 8 2 3 9}$ & Akaike infor criterion & $\mathbf{- 7 . 2 0 9 4 1}$ \\
Adj. R-squared & $\mathbf{0 . 7 6 2 3}$ & &
\end{tabular}

Note: ${ }^{\wedge}$ denote inestimable values

\section{Normality test (SK): $\mathbf{0 . 9 5 9 7}$}

Heteroscedasticity test (B-P): $\mathbf{0 . 9 7 5 4}$
Serial Correlation Test (D-W): $\mathbf{1 . 8 5 3 4 7 3}$

Specification (Ramsey RESET): $\mathbf{0 . 1 7 9 6}$

The estimated coefficients of the long run relationship show that only inflation is statistically significant with a positive sign. This result implies that the past trend of inflation had an propitious impact on the return on assets. The reason for this is not far-fetched, an increase in inflation will result into bank's better performance in the sense that when average prices are increasing, household demand for money also increases due to a decrease in the purshing power of a currency. Consequently, banks wil make a greater percentage of profits in relation to their overall resources.

On the other hand, the long run coefficient of cost-to-income ratio is negative but highly statistically significant at $1 \%$ significant level. We are therefore, $99 \%$ confident that the past trend of cost-to-income had an adverse impact on commercial bank's return on assets in Malawi. It has already been shown that commercial banks in Malawi kept their cost to generate income at an average value of $29.75 \%$, however, this had a negative impact over the period of this study. This can be explained in such a way that keeping costs low was as a result of sacrifising innovation and growth of banks, for example, the construction of more branches, planting of more ATMs, adoption of new technology, employing highly skilled managers and workers among others.

Surprisingly, the estimated coefficient of the short run relationship for all models are barely statistically significant. For example, all lags for Inflation are inestimable, one lag for bank concentration is inestimable and the other lag is insignificant. All lags for cost-to-income ratio are estimable but highly insiginificant with probabilities of $15 \%$ and $36 \%$ far higher than the $5 \%$ p-value. 
Table 5.2c: Error Correction model for ROE (short and long-run model)

Dependent Variable: $\Delta \ln R O E$

\begin{tabular}{|c|c|c|c|c|c|}
\hline \multicolumn{6}{|c|}{ Long-run results } \\
\hline Regressor & Coefficient & Standard Error & & t-Statistic & Prob (t-Statistic) \\
\hline Constant & .0106954 & 0.0463653 & & 0.23 & 0.820 \\
\hline$\triangle \operatorname{lnINFL}$ & .1970165 & 0.2000045 & & 0.99 & 0.337 \\
\hline$\Delta \operatorname{lnCTY}$ & -2.898406 & 0.7871172 & & -3.68 & 0.002 \\
\hline$\triangle \operatorname{lnCON}$ & -1.729296 & 1.866931 & & -0.93 & 0.366 \\
\hline \multicolumn{6}{|c|}{ Short run results } \\
\hline D1. $\Delta \operatorname{lnINFL}$ & 0.0508385 & 0.1645381 & & 0.31 & 0.761 \\
\hline LD. $\Delta \operatorname{lnINFL}$ & 0.1879874 & 0.1079446 & & 1.74 & 0.098 \\
\hline $\mathrm{D} 1 . \Delta \operatorname{lnCTY}$ & 0.0547226 & 0.9644058 & & 0.06 & 0.955 \\
\hline LD. $\Delta \operatorname{lnCTY}$ & -0.2950812 & 0.1486463 & & -1.99 & 0.062 \\
\hline $\mathrm{D} 1 . \Delta \ln C O N$ & $\wedge$ & $\wedge$ & $\wedge$ & & \\
\hline LD. $\Delta \ln C O N$ & $\wedge$ & $\wedge$ & $\wedge$ & & \\
\hline$\overline{\text { ECTt-1 }}$ & -0.9530778 & 0.1941551 & & -4.91 & 0.000 \\
\hline R-squared & 0.8774 & \multicolumn{3}{|c|}{ Akaike infor criterion } & -6.90399 \\
\hline Adj. R-squared & 0.8258 & & & & \\
\hline Normality test (SK): & 0.9597 & \multicolumn{4}{|c|}{ Serial Correlation Test (D-W): $\mathbf{1 . 9 3 3 1 2}$} \\
\hline Heteroscedasticity te & P): $\mathbf{0 . 8 5 4 7}$ & \multicolumn{4}{|c|}{ Specification (Ramsey RESET): $\mathbf{0 . 1 9 3 3}$} \\
\hline
\end{tabular}

The estimated coefficients of the long run relationship for ROE model show that cost-to-income ratio is negative but very statistically significant at $1 \%$ significance level. This result implies that the past trend of costto-income had an adverse impact on the return on equity just like on return on assets. Indeed, keeping costs low at the expense of innovation and renovation, company expansion, human resource development and competitiveness as well as the quality of service delivery will likely lower the generated returns on common stock received from commercial bank's shareholders

In the short-run, the estimated coefficients of the first lag of inflation and cost-to-income may be accepted to be significant at $10 \%$ significance level since the convection level of significance is $5 \%$. While inflation shows a positive sign, it implies that we can be $90 \%$ confident that in the short run during this period, shareholders capital will generate less income. This could be because people may be spending from their savings and not bank loans in the short run at ceteris paribus. 
Table 5.2d: Error Correction model for NIM (short and long-run model)

Dependent Variable: $\Delta \operatorname{lnNIM}$

\begin{tabular}{|c|c|c|c|c|}
\hline \multicolumn{5}{|c|}{ Long-run results } \\
\hline Regressor & Coefficient & Standard Error & t-Statistic & Prob (t-Statistic) \\
\hline Constant & 0.0062218 & 0.0375031 & 0.17 & 0.870 \\
\hline$\triangle \operatorname{lnINFL}$ & 0.1626524 & 0.1467474 & 1.11 & 0.282 \\
\hline$\Delta \operatorname{lnCTY}$ & -0.8800888 & 0.4211387 & -2.19 & 0.050 \\
\hline$\triangle \operatorname{lnCON}$ & -0.0704453 & 1.06818 & -0.07 & 0.948 \\
\hline \multicolumn{5}{|c|}{ Short run results } \\
\hline D1. $\Delta \ln I N F L$ & -0.0978401 & 0.1600682 & -0.61 & 0.549 \\
\hline LD. $\Delta \operatorname{lnINFL}$ & 0.0177877 & 0.110145 & 0.16 & 0.874 \\
\hline L2D. $\Delta \operatorname{lnINFL}$ & -0.0689763 & 0.0796242 & -0.87 & 0.398 \\
\hline $\mathrm{D} 1 . \Delta \operatorname{lnCTY}$ & 1.679252 & 0.5892211 & 2.85 & 0.011 \\
\hline LD. $\Delta \operatorname{lnCTY}$ & $\wedge$ & $\wedge$ & $\wedge$ & $\wedge$ \\
\hline L2D. $\Delta \operatorname{lnCTY}$ & $\wedge$ & $\wedge$ & $\wedge$ & $\wedge$ \\
\hline$\overline{\mathrm{D} 1 . \Delta \ln C O N}$ & $\wedge$ & $\wedge$ & $\wedge$ & $\wedge$ \\
\hline LD. $\Delta \ln C O N$ & $\wedge$ & $\wedge$ & $\wedge$ & $\wedge$ \\
\hline L2D. $\Delta \ln C O N$ & $\wedge$ & $\wedge$ & $\wedge$ & $\wedge$ \\
\hline$\overline{\text { ECTt-1 }}$ & -1.218214 & 0.1934163 & -6.30 & 0.000 \\
\hline \multicolumn{2}{|c|}{ R-squared: 0.8263} & \multicolumn{3}{|c|}{ Akaike infor criterion: $\quad \mathbf{- 5 . 8 8 0 7 1}$} \\
\hline \multicolumn{2}{|c|}{ Adj. R-squared: 0.7492} & \multicolumn{3}{|c|}{ Serial Correlation Test (D-W): $\mathbf{2 . 2 0 9 5 0 7}$} \\
\hline \multicolumn{2}{|c|}{ Normality test (SK): $\mathbf{0 . 9 5 9 7}$} & \multicolumn{3}{|c|}{ Specification (Ramsey RESET): $\mathbf{0 . 1 1 7 8}$} \\
\hline Heteroscedastic & 0.1288 & & & \\
\hline
\end{tabular}

$\wedge$ for inestimable values, BP for Breush Pagan, SK: Skewness-Kurtosis, DW for Durbin Watson

Similarly, the estimated coefficients of the long run relationship for NIM model show that cost-to-income ratio is negative but statistically significant at 5\%. Therefore, we are $95 \%$ confident to say that the results implies that the past trend of cost-to-income had an adverse impact on net interest margin just like on return on assets and return on equity. That is, an increase in the cost-to-income ratio will result in the decrease in bank's profitbility on interests recieved from lending relative to interests paid on deposits.

The estimated coefficient of the short run relationship for NIM model show that it is only cost-to-income awhich is negative and significant at 5\%. This implies that an increase in the cost-to-income ratio will result to a decrease in bank's interest earnings from lending relative to interest payments on deposits.

The equilibrium error correction coefficient (ECT) estimate for ROA, ROE and NIM of $-0.7739,-0.9530$ and -1.218 are highly statistically significant at $5 \%$, with the correct sign. This implies a high speed of adjustment to equilibrium after market shocks (supply or demand side). Approximately $77 \%, 95 \%$ ans $121 \%$ of disequilibrias from various shocks converge back to the long run equilibrium in the current year.

The Cusum square stability test indicate that all models are stable and fall with $5 \%$ significance level throughout the period of study as shown in the figure below; 
Figure 1: Cusum Square Stability test at 5\% significant level
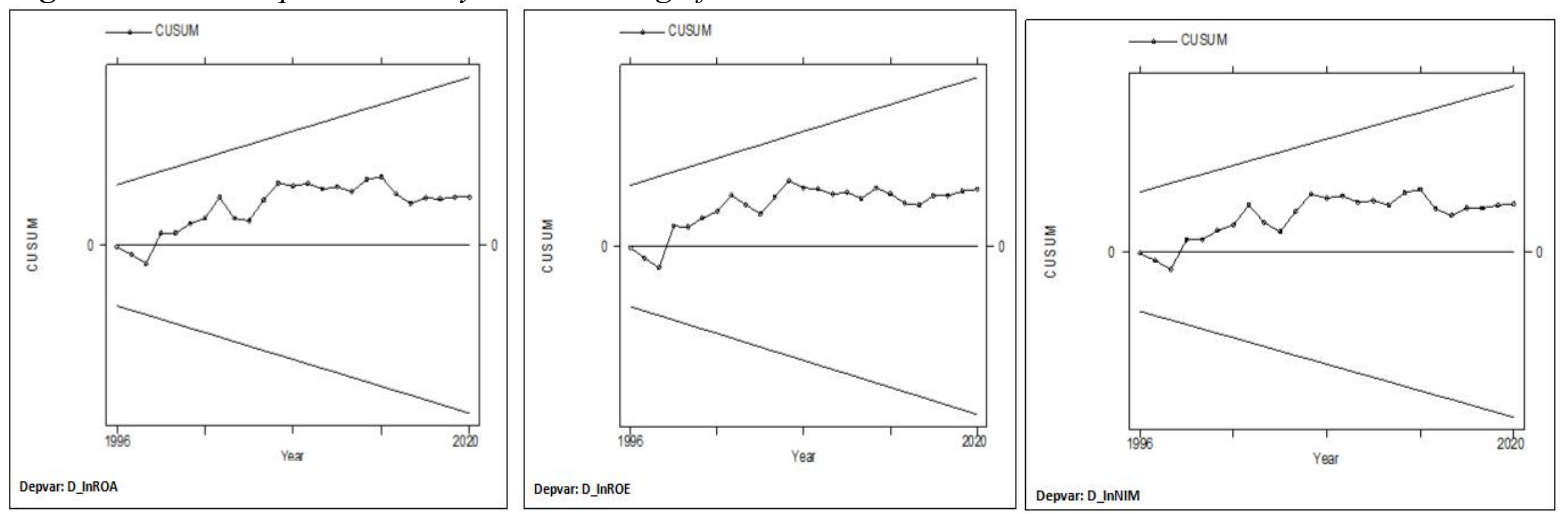

\subsection{Granger Causality Test/Block Exogeneity Wald Tests}

Causality test was conducted among the dependent variables of the three models used in order to determine the relationship between the various measures of commercial banks performance. Table 5.4a below shows the results of the VAR Granger causality/Block Exogeneity Wald tests

Table 5.4: VEC Granger Causality/Block Exogeneity Tests

\begin{tabular}{|c|c|c|c|c|c|c|c|c|}
\hline \multicolumn{3}{|c|}{ Depvar: $\Delta \ln R O A$} & \multicolumn{3}{|c|}{ Depvar: $\Delta \ln R O E$} & \multicolumn{3}{|c|}{ Depvar: $\Delta \ln N I M$} \\
\hline Excluded & $\mathrm{F}$ & Df & Excluded & $\mathrm{F}$ & Df & Excluded & $\mathrm{F}$ & Df \\
\hline$\Delta \ln \mathrm{ROE}$ & 0.05261 & 1 & $\Delta \ln \mathrm{ROA}$ & 0.3331 & 1 & $\Delta \ln \mathrm{ROA}$ & 2.3783 & 1 \\
\hline$\Delta \ln N I M$ & 0.22437 & 1 & $\Delta \ln$ NIM & $3.7767 *$ & 1 & $\Delta \ln R O E$ & 0.00169 & 1 \\
\hline ALL & 1.272 & 2 & ALL & 2.3052 & 2 & ALL & $6.5082 * * *$ & 2 \\
\hline
\end{tabular}

Note: $* * *$ significance at $1 \% ; * *$ significance at $5 \% ; *$ significance at $10 \%$

Results from VEC Granger causality test indicate that return on equity and net interest rates does not granger and so is the null block exogeneity which is rejected when return on assets is taken as a dependent variable. albeit, a $10 \%$ significance of net interest margin, we fail to reject the null hypothesis that return on assets and net interest margin do not granger cause return on assets and so is the null block exogeneity. On the hand, return on assets and return on equity do not individually granger cause net interest margin. However, when all the returns are taken together, we reject the null block exogeneity and conclude that return on assets and return on equity granger causes net interest margin. This is indeed true in the sense that an increase in earnings from commercial banks resources and shareholder's investments will increase the funds available for loans and hence more interest on loans than deposits.

\subsection{Policy Implication}

Various policy implications that can be drawn from this paper are:

The banking sector in Malawi is determined by macroeconomic, bank-specific and financial structure such as inflation, cost-to-income ratio and bank concentration ratio. The results have shown a strong positive and significant relationship between inflation and commercial bank performance through return on asset indicator. This is consistent with the findings of Mkandawire (2016) who observed that commercial banks thrive well during periods of high inflationary pressures. This could presumably be due to high interest rates as the central bank tighten monetary policy in an effort to combat inflation. Other studies have also found a positive long run relationship between inflation and commercial bank's performance (Bourke, 1989; Molyneux \& Thornton, 1992; Demirguc-Kunt \& Huizinga, 1998)

Thus, policy measures must be put in place to prepare banks for an inflationary period. Also, efficient methods must be put in place to ensure that banks continue to operate and meet the needs of their customers. That is, the various fiscal and monetary policy measures needed to ensure macroeconomic stability must be adopted to ensure the realization of market stability including the banking sector. One may argue that the Reserve Bank of Malawi should lower the cash reserve ratio during an inflationary period to allow banks service the increase in demand for money. The essence being that increasing money supply may worsen the situation in the long run.

The results have also shown a strong negative and significant relationship between cost-to-income ratio and 
bank performance through all indicators: Return of assets, return on equity and net-interest margin. This implies that lower production costs do not always imply efficiency in overall resource use. As a bank-specific factor, commercial banks need to increase their costs in areas that have high rate of return on assets and equity. This could be through human development, employing skilled workers, increasing awareness campaigns, opening more branches, promoting research and development and many more. These expenses may increase productivity of workers as well as customer satisfaction which may prove key to the profitability of commercial banks.

The results also depict that return on assets and equity causes net interest margin. This means increase in earnings from interests on loans depend on the efficient use of the resources of a bank and prudent management of shareholder's investments. To increase profitability, it is suggested that commercial banks decrease the amount of assets by auctioning the less productive assets, use financial leverage, and then distribute idle cash to profit on interests.

\subsection{Summary and Conclusion}

This paper analysed the determinants of commercial bank's performance in the category of macroeconomic factors, bank-specific factors and financial structure factors. The study used an autoregressive distributed lag (ARDL) approach for a period between 1990 to 2020. The results reveal that the economy's inflation and bank's cost-to-income ratio in Malawi influences commercial bak's performance. To this end, the study suggests that the Reserve Bank as the main regulatory authority of the financial sector in Malawi is responsible for enhancing the performance of commercial banks. For example, during an inflationary period, they may lower the cash reserve ratio. This implies that commercial banks will have more cash to meet the sudden increase in demand for money. Furthermore, the papers suggests that commercial banks should not focus on keeping costs low in an economy that developing with many potential areas of improvement. Rather they should focus on spending money on an individual innovation and growth. This paper has proved that keeping costs low does not translate to efficiency as sometimes it may be idleness. That is, lack of critical thinking on optimization of the use of overall resources of the bank by its managers.

\section{References}

Alper, Değer \& Anbar, Adem. (2011). Bank Specific and Macroeconomic Determinants of Commercial Bank Profitability: Empirical Evidence from Turkey. 2. 139-139.

Bourke, P. (1989). "Concentration and Other Determinants of Bank Profitability in Europe, North America and Australia," Journal of Banking and Finance 13, 65-79.

Chirwa, E.W. (2003). Determinants of commercial bank's profitability in Malawi: a cointegration approach. Applied Financial Economics, 13(8), DOI: 10.1080/09603100220000200933.

Delis, M \& Staikouras, C. (2006). Determinants of Bank Profitability In The South Eastern European Region. University Library of Munich, Germany, MPRA Paper.

Demirg üç-Kunt, A. and A. Huizinga (1998). "Determinants of Commercial Bank Interest Margins and Profitability: Some International Evidence," World Bank Economic Review 13, 379-408.

Dickey, D.A. and Fuller, W.A. (1079). Distribution of the estimators for autoregressive time series with a unit root, Journal of the American Statistical Association, vol. 74, no. 366a, pp. 427-431.

Elliott, G., Rothenberg, T.J., and J. H. Stock. (1996). Efficient tests for an autoregressive unit root," Econometrica, vol. 64, no. 4, pp. 813-836.

Granger, C. W., \& Newbold, P. (1974). Spurious regressions in econometrics. Journal of Econometrics, 2(2), 111-120.

Harris, R. and Sollis, R. (2003), Applied Time Series modelling and Forecasting. Chichester: Wiley and Sons.

Jeng, L.W., Ramasamy, S., Rasiah, D., Yen, P.Y.Y., \& Pillay, S.D. (2018). Determinants of local commercial bank's performance in Malaysia. International Journal of Engineering \& Technology. 7(3), 457 - 463.

Kaluwa, B. \& Chirwa, G.C. (2017) Competition, regulation and banking industry pricing conduct in Malawi. African Review of Economics and Finance. Vol. 9, No. 2. Pp. 3 - 17.

Khan et al. (2020) Consumption-based carbon emissions and trade nexus: evidence from nine oil exporting countries, Energy Economics, vol. 89, pp. 1-13.

Khan, $\mathrm{Z}$ et al. (2020). Consumption-based carbon emissions and international trade in G7 countries: the role of environmental innovation and renewable energy, Science of The Total Environment, vol. 730, pp. 1-10.

KPMG. (2017). Malawi Economic Snapshot H2, 2017: Trade and investment SWOT. Swiss, KPMG International Cooperative.

Kwiatkowski, D. (1992). Testing the null hypothesis of stationarity against the alternative of a unit root: How sure are we that economic time series have a unit root? Journal of Econometrics, vol. 54, no. 1-3, pp. 159$178,1992$.

Kwiatkowski, Det al., Testing the null hypothesis of stationarity against the alternative of a unit root: how sure are 
Lipunga, A.M. (2014). Determinants of profitability of listed commercial banks in Developing Countries: Evidence from Malawi. Research Journal of Finance and Accounting.

Mkandawire, P.M. (2016). An analysis of the determinants of bank performance in Malawi: A case of listed commercial banks. MPRA Paper No. 92392. Retrieved from: https://mpra.ub.uni-muenchen.de/92392/, Assessed on 23/08/2021

Moulyneux, P. and J. Thornton (1992). "Determinants of European Bank Profitability: A Note," Journal of Banking and Finance 16, 1173-1178.

Ozili, P.K. (2019). Determinants of Banking Stability in Nigeria. CBN Bullion, Vol. 43 No 2, $2^{\text {nd }}$ Quarter.

Ozili, P.K. (2019). Determinants of Banking Stability in Nigeria. MPRA Paper No. 94092. [online]. https://mpra.ub.uni-muenchen.de/94092/. Accessed on 23 August, 2021.

Ozili, P.K. (2019). Determinants of Banking Stability in Nigeria. CBN Bullion, Vol. 43 No 2, 2 ${ }^{\text {nd }}$ Quarter.

Ozili, P.K. (2018), "Banking stability determinants in Africa", International Journal of Managerial Finance, Vol. 14 No. 4, pp. 462-483.[online] https://doi.org/10.1108/IJMF-01-2018-0007. Accessed on 23 August, 2021.

Pesaran, M. H., Shin, Y., \& Smith, R. J. (2001). Bounds testing approaches to the analysis of level relationships. Journal of Applied Econometrics, 16(3), 289-326.

Phillips, P.C.B and Perron, P. (1988). Testing for a unit root in time series regression, Biometrika, vol. 75, no. 2 , pp. 335-346, 1988.

Udoh, E., Afangideh, U., \& Udeaja, E. A. (2015). Fiscal decentralization, economic growth and human resource development in Nigeria: Autoregressive Distributed Lag (ARDL) approach, CBN Journal of Applied Statistics, ISSN 2476-8472, The Central Bank of Nigeria, Abuja, Vol. 06, no. 1, pp. 69-93 